\title{
Phenology of aquatic insects in a protected wetland (Natura 2000 network) in northwestern Spain
}

\author{
Amaia Pérez-Bilbao*, Ana Isabel Alonso and Josefina Garrido \\ Department of Ecology and Animal Biology, Faculty of Biology, University of Vigo. 36310, Vigo, Spain. Email: \\ amaiapb@uvigo.es \\ *Corresponding author: amaiapb@uvigo.es
}

Received: 10/3/10 Accepted: 21/7/10

\begin{abstract}
Phenology of aquatic insects in a protected wetland (Natura 2000 network) in northwestern Spain

The aim of this study was to gather new data about the life cycle phenologies of several species of aquatic insects in the "Gándaras de Budiño" (Galicia, NW Spain) protected wetland, included in the Natura 2000 network. During an annual cycle (2004-2005), three shallow lakes and four streams were sampled monthly using a semi-quantitative sampling method. The body lengths of the larvae and nymphs of thirteen species were measured, and their life cycles were analysed. All species had univoltine or semivoltine cycles. Additionally, a possible correlation between larval and nymphal lengths and water temperature was examined. We found a significant correlation for two species: the water beetle (Noterus laevis) and the dragonfly (Boyeria Irene). It is important to highlight the presence in the studied area of a species included in the Habitats Directive: the damselfly (Coenagrion mercuriale).
\end{abstract}

Key words: Life cycle, aquatic insects, larvae, wetland, Natura 2000.

\section{RESUMEN}

Fenología de insectos acuáticos en un humedal protegido (Red Natura 2000) del noroeste de España

El objetivo principal de este estudio fue aportar nuevos datos al conocimiento sobre los ciclos de vida de varias especies de insectos acuáticos en un humedal protegido, las Gándaras de Budiño (Galicia, NO España), incluido en la Red Natura 2000. Se muestrearon tres lagunas y cuatro arroyos mensualmente durante un año (2004-2005) mediante un método semicuantitativo. Se midieron las larvas y ninfas de trece especies, y se analizaron sus ciclos de vida. Todas las especies presentaron ciclos univoltinos o semivoltinos. También se examinó la posible correlación entre la longitud de las larvas y ninfas, y la temperatura del agua. Se encontró una correlación significativa para dos especies, el coleóptero acuático Noterus laevis, y la libélula (Boyeria irene). Es importante destacar la presencia de una especie incluida en la Directiva Hábitats, el caballito del diablo (Coenagrion mercuriale).

Palabras clave: Ciclos de vida, insectos acuáticos, larvas, humedal, Natura 2000.

\section{INTRODUCTION}

Wetlands are habitats with high biodiversity (Mitsch \& Gosselink, 2000; Gopal et al., 2001). They have recognised social and economic uses (Chapman et al., 2001). These sites are one of the ecosystems most at risk of being seriously or irreversibly disturbed not only because of their extreme fragility but also because of the human pressure to which they are subjected. The proximity of wetlands to urban areas and the drainage and extension of agricultural lands into these areas negatively impact the shallow water levels found in wetlands. During the twenty-first cen- 
tury, wetland losses reached $40-90 \%$ in a number of north-western European countries (Hull, 1997). In Spain, it was estimated that more than $60 \%$ of wetlands had disappeared by the end of the last century (Casado \& Montes, 1995). Due to this great loss of habitat, many wetland species are endangered. It is well known that wetland management and conservation is closely linked to an understanding of the biodiversity and ecology of the biota they host (Gee et al., 1997; Gaston et al., 2005; Céréghino et al., 2008), and there are an increasing number of studies focusing on this type of habitat (Nicolet et al., 2004; Della Bella et al., 2005; García-Criado et al., 2005; Hinden et al., 2005; Trigal et al., 2006; Oertli et al., 2005, 2008; Garrido \& Munilla, 2008; Pérez-Bilbao \& Garrido, 2008).

Aquatic insects constitute an important part of the animal life within wetlands (Oertli, 1993), and these insects are tightly integrated into the structure and function of their habitats (Cayrou \& Céréghino, 2005). The temporal variability of habitats is a key factor that influences the biodiversity of insect communities (Hanquet et al., 2004). Information on the life cycles of aquatic species is of fundamental importance (Cayrou \& Céréghino, 2005). Knowledge of these life cycles is fairly limited, but in the last decade, interest has increased considerably (Vega \& Durant, 2000; Derka et al., 2004; Cayrou \& Céréghino, 2003; Corbet et al., 2006; López-Rodríguez \& Tierno de Figueroa, 2006; Braccia et al., 2007; Fernández, 2007; Navarro-Martínez et al., 2007). The possible application of this knowledge in the management and conservation of aquatic ecosystems has been discussed (Cayrou \& Céréghino, 2005).

This study provides new data on the life cycle phenologies of several species of aquatic insects in the little-studied area of "Gándaras de Budiño" (NW Spain), which is included in the Natura 2000 network.

\section{MATERIAL AND METHODS}

\section{Study area}

The "Gándaras de Budiño" wetland is located in the province of Pontevedra (NW Spain) (Fig. 1). This wetland is included in the Galician Natura

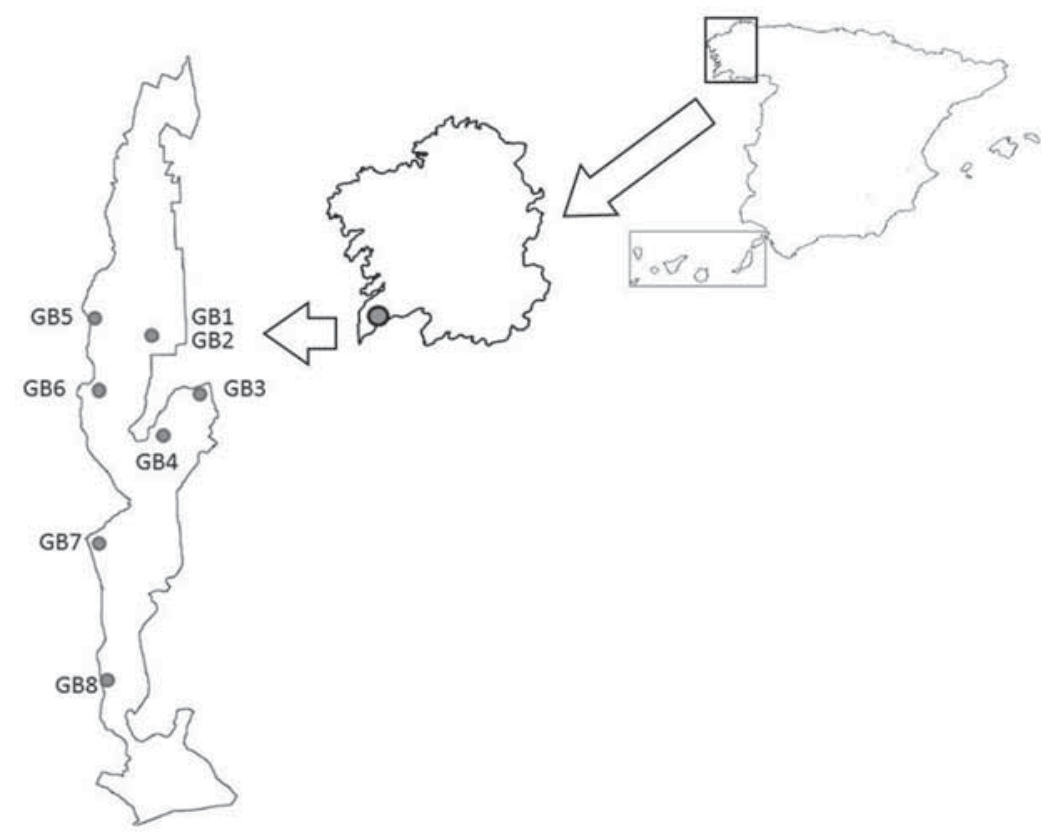

Figure 1. Location of the sampling sites in the studied area. The line delimits the SAC, and the dots represent the sampling sites. Localización de los puntos de muestreo en el área de estudio. La línea delimita el LIC y los puntos representan las estaciones de muestreo. 
2000 network as a Special Area of Conservation (SAC) (site ES1140011) in the Atlantic biogeographical region (DOCE L387 of 29/12/2004). The climate of the area is characterised by an average annual rainfall of $1715 \mathrm{~mm}$ and an average annual temperature of $14^{\circ} \mathrm{C}$. This wetland area includes several permanent ponds, marshes and streams that extend to cover a total area of $834 \mathrm{Ha}$ at an average altitude of $24 \mathrm{~m}$. The water in this wetland comes from the water table and the Louro River, which is one of the tributaries of the Miño River, the main watercourse in the Galician Hydrological Network.

The "Gándaras de Budiño" wetland is a marshy area with an important riparian forest. It is home to species such as Alnus glutinosa (L.) Gaertner, Quercus robur L., Fraxinus excelsior L., Castanea sativa Miller and Salix atrocinerea Brot. Aquatic and peat bog vegetation are also widely represented (Typha latifolia L., Juncus sp. L. or Erica cinerea L.). While it is a place of great interest with regard to vertebrate fauna and flora, there are also important invertebrate communities, including many endemic water beetle species (Pérez-Bilbao \& Garrido, 2008). In the last few years, this area has undergone considerable transformation due to the building of an industrial estate, a road and a railway, which have fragmented the area and seriously damaged the environment.

\section{Sampling}

During an annual cycle, three shallow lakes and four streams (eight points in total) were sam- pled monthly (from February 2004 to February 2005) using a semi-quantitative sampling method (Table 1). The fauna were collected with a round entomological water net $(500 \mu \mathrm{m}$ mesh, $30 \mathrm{~cm}$ diameter and $60 \mathrm{~cm}$ deep), and sweepings were done along a stretch of approximately 5 meters for periods of 1 minute. Invertebrates were preserved in $99 \%$ ethanol in the field and then identified in the laboratory. After identification, organisms were stored in $70 \%$ ethanol in hermetically sealed tubes. Odonata adults were observed flying, but they were not captured. The water temperature $\left({ }^{\circ} \mathrm{C}\right)$ was measured at each sampling point where the fauna were sampled.

\section{Data analysis}

Thirteen species (seven Odonata, two Heteroptera and four Coleoptera) were selected for this study. Other species collected in the samples were not used because the number of individuals was too low to analyse. The total body length of all collected larvae and nymphs was measured with the ocular micrometer of a binocular microscope (Olympus BX51 model). All data from the different sampling points were used together to analyse the life cycles of the studied species. Box plots were constructed to represent these life cycles. The correlation between the water temperature and the total body length of the larvae was calculated. Both analyses were performed using Statistica 7.0 for Windows (Statsoft, 2004). The data were previously tested for a normal distribution using the Kolmogorov-Smirnov test.

Table 1. Sampling sites in the studied area, their respective codes, the type of ecosystem and their coordinates. Estaciones de muestreo en el área de estudio, su respectivo código, tipo de ecosistema y coordenadas.

\begin{tabular}{|c|c|c|c|c|}
\hline \multirow{2}{*}{$\begin{array}{l}\text { Sampling sites name } \\
\text { Laguna de Budiño (Observatorios) }\end{array}$} & \multirow{2}{*}{$\begin{array}{l}\text { Code } \\
\text { GB1 }\end{array}$} & \multirow{2}{*}{$\begin{array}{l}\text { Ecosystem } \\
\text { Pond }\end{array}$} & \multicolumn{2}{|c|}{ Coordinates } \\
\hline & & & $\mathrm{N} 42^{\circ} 06^{\prime} 46.6^{\prime \prime} \mathrm{W}$ & $008^{\circ} 37^{\prime} 42.37^{\prime \prime}$ \\
\hline Laguna de Budiño (Canal periférico) & GB2 & Pond & $\mathrm{N} 42^{\circ} 06^{\prime} 56.63^{\prime \prime} \mathrm{W}$ & $008^{\circ} 37^{\prime} 44.49^{\prime \prime}$ \\
\hline Viza & GB3 & Pond & $\mathrm{N} 42^{\circ} 06^{\prime} 16.38^{\prime \prime} \mathrm{W}$ & $008^{\circ} 37^{\prime} 22.95^{\prime \prime}$ \\
\hline Orbenlle & GB4 & Pond & $\mathrm{N} 42^{\circ} 06^{\prime} 02.6^{\prime \prime} \mathrm{W}$ & $008^{\circ} 37^{\prime} 50.68^{\prime \prime}$ \\
\hline Folón & GB5 & Stream & $\mathrm{N} 42^{\circ} 07^{\prime} 06.75^{\prime \prime} \mathrm{W}$ & $008^{\circ} 39^{\prime} 11.31^{\prime \prime}$ \\
\hline Penedo & GB6 & Stream & $\mathrm{N} 42^{\circ} 06^{\prime} 22.74^{\prime \prime} \mathrm{W}$ & $008^{\circ} 38^{\prime} 54.52^{\prime \prime}$ \\
\hline San Simón & GB7 & Stream & $\mathrm{N} 42^{\circ} 05^{\prime} 54.72^{\prime \prime} \mathrm{W}$ & $008^{\circ} 38^{\prime} 43.4^{\prime \prime}$ \\
\hline Delque & GB8 & Stream & $\mathrm{N} 42^{\circ} 04^{\prime} 06.91^{\prime \prime} \mathrm{W}$ & $008^{\circ} 38^{\prime} 18.72^{\prime \prime}$ \\
\hline
\end{tabular}




\section{RESULTS AND DISCUSSION}

A total of 2917 adults, nymphs and larvae (996 Odonata, 675 Hemiptera and 1246 Coleoptera) were studied (Table 2). Of the Odonata, three species belonged to the family Coenagrionidae (Coenagrion mercuriale (Charpentier, 1840), Coenagrion puella (L., 1758) and Pyrrhosoma nymphula (Sulzer, 1776)), one to Calopterygidae (Calopteryx virgo (L., 1758)), one to Aeshnidae (Boyeria irene (Fonscolombe, 1838)), one to Gomphidae (Onychogomphus uncatus (Charpentier, 1840)) and one to Cordulegastridae (Cordulegaster boltonii (Donovan, 1807)). The two species of Heteroptera belonged to the families Gerridae (Aquarius najas (De Geer, 1773)) and Notonectidae (Anisops sardeus Herrich-Schaeffer, 1849). Most Coleoptera (three species) belonged to the family Elmidae (Dupophilus brevis (Mulsant \& Rey, 1872), Limnius perrisi carinatus (Pérez-Arcas, 1865 ) and Limnius volckmari (Panzer, 1793)), and the other species belonged to the family Noteridae (Noterus laevis (Sturm, 1834)).

We should highlight the presence of the damselfly C. mercuriale, which is included in Annex II of the Habitats Directive. This species is considered of "special interest" in the National Cat- alogue of Threatened Species (MARM, 2008). $C$. mercuriale and $O$. uncatus are also included in the Red Book of Invertebrates of Spain as "vulnerable" (Verdú \& Galante, 2006). However, C. mercuriale is widespread in Galician coastal areas, and it is not rare on the regional scale (Azpilicueta et al., 2007).

Some species were captured only in stagnant water (N. laevis, A. sardeus, P. nymphula, $C$. puella and C. mercuriale) or only in running water (D. brevis, L. perrisi carinatus, A. najas, B. irene, $O$. uncatus, $C$. boltonii and $C$. virgo), but one species, $L$. volckmari, was collected in both types of ecosystem, although this species is usually found in running waters (Garrido, 1990).

The last nymphal instars and the highest nymph abundance were observed in the summer for A. najas, in the spring for $N$. laevis, and in the autumn-winter for $P$. nymphula and C. puella. The last larval instars of $O$. uncatus and $C$. boltonii appeared in the spring, autumn and winter, and those of L. perrisi, L. volckmari, $B$. irene, $C$. mercuriale and $C$. virgo appeared in the spring, summer and winter. Larvae of $D$. brevis were observed in the autumn and winter, and nymphs of $A$. sardeus were found in the winter. Larvae of $L$. volckmari, D. brevis, B. irene, $C$. boltonii and $O$. uncatus were captured through-

Table 2. List of the thirteen species collected at the sampling sites and the state in which they were captured. A: adults, L: larvae, $\mathrm{N}$ : nymphs. Listado de las trece especies recogidas con los puntos de muestreo y estadio en los que se capturaron. A: adultos, L: larvas, $N$ : ninfas.

\begin{tabular}{|c|c|c|c|c|c|c|c|c|c|c|c|c|c|}
\hline \multirow{2}{*}{ Species } & \multicolumn{13}{|c|}{ Month } \\
\hline & Feb & Mar & Apr & May & Jun & Jul & Aug & Sept & Oct & Nov & Dec & Jan & Feb \\
\hline Calopteryx virgo (Linnaeus 1758) & $\mathrm{L}$ & $\mathrm{L}$ & $\mathrm{L}$ & $\mathrm{L}$ & $\mathrm{L}$ & $\mathrm{L}$ & & & $\mathrm{L}$ & $\mathrm{L}$ & $\mathrm{L}$ & & $\mathrm{L}$ \\
\hline Pyrrhosoma nymphula (Sulzer 1776) & $\mathrm{L}$ & & & & & & & $\mathrm{L}$ & $\mathrm{L}$ & $\mathrm{L}$ & $\mathrm{L}$ & $\mathrm{L}$ & \\
\hline Coenagrion mercuriale (Charpentier 1840) & $\mathrm{L}$ & & & $\mathrm{L}$ & & $\mathrm{L}$ & $\mathrm{L}$ & & $\mathrm{L}$ & $\mathrm{L}$ & $\mathrm{L}$ & & \\
\hline Coenagrion puella (Linnaeus 1758) & & $\mathrm{L}$ & $\mathrm{L}$ & $\mathrm{L}$ & $\mathrm{L}$ & & & $\mathrm{L}$ & $\mathrm{L}$ & & $\mathrm{L}$ & $\mathrm{L}$ & $\mathrm{L}$ \\
\hline Boyeria irene (Fonscolombe 1838) & $\mathrm{L}$ & $\mathrm{L}$ & $\mathrm{L}$ & $\mathrm{L}$ & $\mathrm{L}$ & $\mathrm{L}$ & $\mathrm{L}$ & $\mathrm{L}$ & $\mathrm{L}$ & $\mathrm{L}$ & $\mathrm{L}$ & $\mathrm{L}$ & $\mathrm{L}$ \\
\hline Onychogomphus uncatus (Charpentier 1840) & $\mathrm{L}$ & $\mathrm{L}$ & $\mathrm{L}$ & $\mathrm{L}$ & $\mathrm{L}$ & $\mathrm{L}$ & $\mathrm{L}$ & $\mathrm{L}$ & $\mathrm{L}$ & $\mathrm{L}$ & $\mathrm{L}$ & $\mathrm{L}$ & $\mathrm{L}$ \\
\hline Cordulegaster boltonii (Donovan 1807) & $\mathrm{L}$ & $\mathrm{L}$ & $\mathrm{L}$ & $\mathrm{L}$ & $\mathrm{L}$ & $\mathrm{L}$ & $\mathrm{L}$ & $\mathrm{L}$ & $\mathrm{L}$ & $\mathrm{L}$ & $\mathrm{L}$ & $\mathrm{L}$ & $\mathrm{L}$ \\
\hline Aquarius najas (De Geer 1773) & A & A & $\mathrm{A}$ & $\mathrm{A}$ & $\mathrm{A}+\mathrm{N}$ & $\mathrm{A}+\mathrm{N}$ & $\mathrm{A}+\mathrm{N}$ & A & A & A & & $\mathrm{A}$ & A \\
\hline Anisops sardeus Herrich-Schaeffer 1849 & A & A & & & $\mathrm{N}$ & $\mathrm{N}$ & $\mathrm{N}$ & $\mathrm{A}+\mathrm{N}$ & $\mathrm{N}$ & A & $\mathrm{N}$ & A & \\
\hline Noterus laevis Sturm 1834 & $\mathrm{~L}$ & A & $\mathrm{A}+\mathrm{L}$ & $\mathrm{A}+\mathrm{L}$ & $\mathrm{A}+\mathrm{L}$ & $\mathrm{A}+\mathrm{L}$ & $\mathrm{L}$ & & & & & & \\
\hline Dupophilus brevis Mulsant \& Rey 1872 & $\mathrm{~A}+\mathrm{L}$ & $\mathrm{A}+\mathrm{L}$ & $\mathrm{A}+\mathrm{L}$ & $\mathrm{A}+\mathrm{L}$ & $\mathrm{A}+\mathrm{L}$ & $\mathrm{L}$ & $\mathrm{L}$ & $\mathrm{L}$ & $\mathrm{L}$ & $\mathrm{A}+\mathrm{L}$ & $\mathrm{L}$ & $\mathrm{A}+\mathrm{L}$ & $\mathrm{A}+\mathrm{L}$ \\
\hline Limnius perrisi carinatus (Pérez-Arcas 1865) & $\mathrm{A}+\mathrm{L}$ & $\mathrm{A}+\mathrm{L}$ & $\mathrm{A}+\mathrm{L}$ & $\mathrm{A}+\mathrm{L}$ & $\mathrm{A}+\mathrm{L}$ & $\mathrm{A}+\mathrm{L}$ & $\mathrm{A}+\mathrm{L}$ & A & & $\mathrm{A}+\mathrm{L}$ & $\mathrm{L}$ & $\mathrm{A}+\mathrm{L}$ & $\mathrm{A}+\mathrm{L}$ \\
\hline Limnius volckmari (Panzer 1793) & $\mathrm{A}+\mathrm{L}$ & $\mathrm{A}+\mathrm{L}$ & $\mathrm{A}+\mathrm{L}$ & $\mathrm{A}+\mathrm{L}$ & $\mathrm{A}+\mathrm{L}$ & $\mathrm{A}+\mathrm{L}$ & $\mathrm{A}+\mathrm{L}$ & $\mathrm{A}+\mathrm{L}$ & $\mathrm{A}+\mathrm{L}$ & $\mathrm{A}+\mathrm{L}$ & $\mathrm{A}+\mathrm{L}$ & $\mathrm{A}+\mathrm{L}$ & $\mathrm{A}+\mathrm{L}$ \\
\hline
\end{tabular}



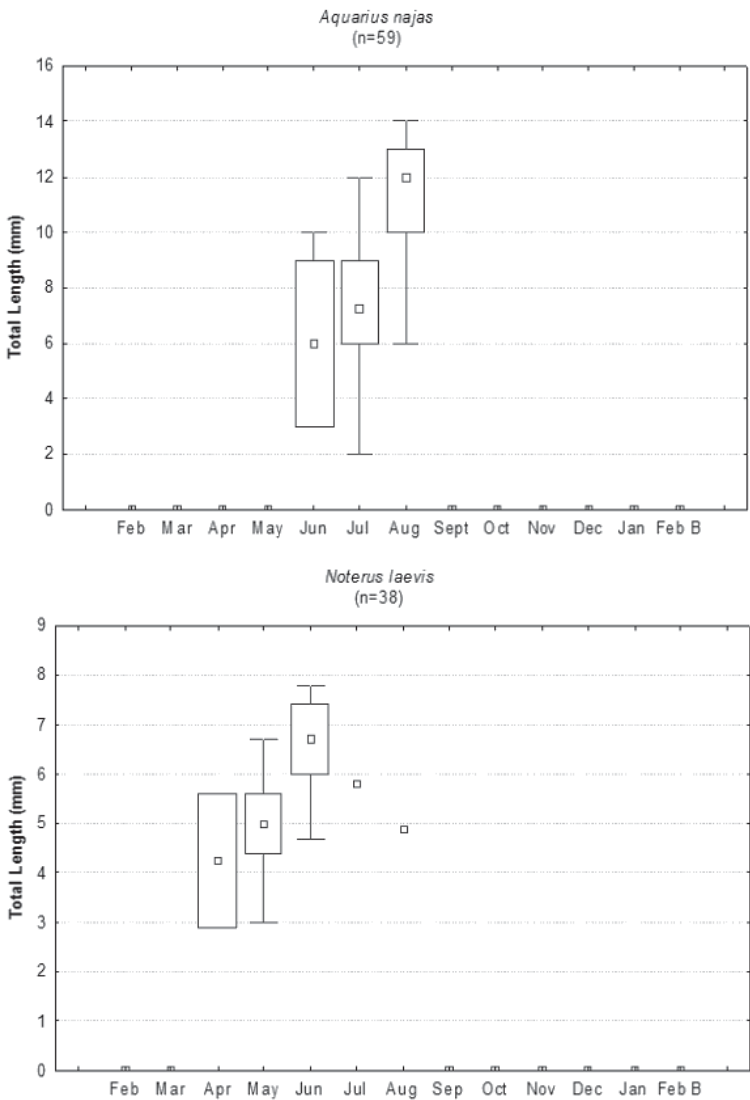

Figure 2. Two examples of box plots representing the univoltine life cycles of the species Aquarius najas (up) and Noterus laevis (down). The small square represents the median, the box represents the range between the first $(25 \%)$ and third $(75 \%)$ quartiles, and the bars represent the non-outlier range. Dos ejemplos de box plots que representan el ciclo univoltino de las especies Aquarius najas (superior) y Noterus laevis (inferior). El cuadrado pequeño representa la mediana, la caja el rango entre el cuartil uno (25\%) y el tres (75\%), y las barras el rango de valores no atípicos.

out the year while $C$. virgo and $C$. mercuriale were not collected in some samples.

$C$. virgo adults were observed in the springsummer, $P$. nymphula and $C$. puella adults were observed in the spring, and $O$. uncatus and $C$. boltonii adults were observed in the summer. Imagoes of $C$. mercuriale and $B$. irene were not seen during the study. A. sardeus adults were captured in the autumn-winter, $D$. brevis adults were captured in the winter-spring, and $N$. laevis adults were captured in the spring-early summer. $A$. $n a$ jas, L. perrisi carinatus and L. volckmari adults were collected throughout the year.
The term "voltinism" denotes the number of generations completed within a year (Ferreras-Romero, 1997). In our study, the life cycle patterns of the thirteen studied species could be divided into two main types: (1) univoltine, species that complete one generation per year; in our case, P. nymphula, C. puella, A. najas, A. sardeus and $N$. laevis (Fig. 2); and (2) semivoltine, species that complete one generation in two years; in our study, $C$. virgo, $C$. mercuriale, $O$. uncatus, $C$. boltonii, B. irene, D. brevis, L. perrisi carinatus and L. volckmari (Fig. 3).
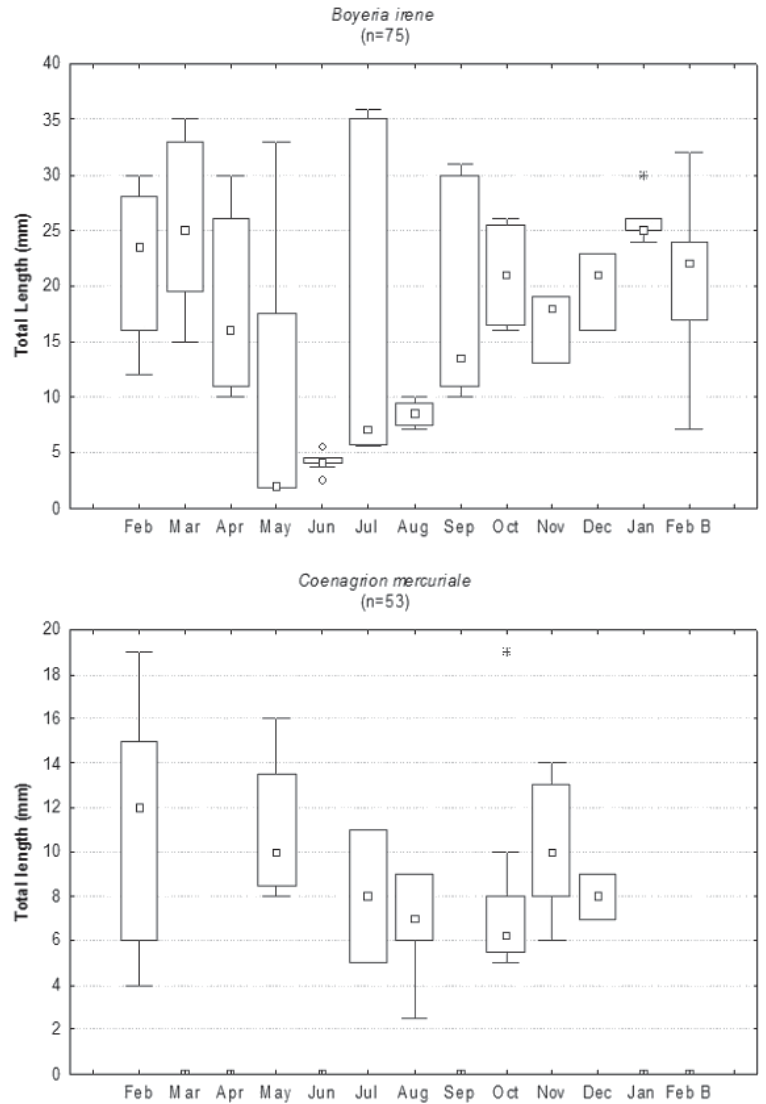

Figure 3. Two examples of box plots representing the semivoltine life cycles of the species Boyeria irene (up) and Coenagrion mercuriale (down). The small square represents the median, the box represents the range between the first $(25 \%)$ and third $(75 \%)$ quartiles, the bars represent the non-outlier range, asterisks represent extreme values, and the circles represent the outliers. Dos ejemplos de box plots que representan el ciclo semivoltino de las especies Boyeria irene (superior) y Coenagrion mercuriale (inferior). El cuadrado pequeño representa la mediana, la caja el rango entre el cuartil uno (25\%) y el tres (75\%), las barras el rango de valores no atípicos, el asterisco los valores extremos y el círculo los atípicos. 
The three species of the family Elmidae (D. brevis, L. perrisi carinatus and $L$. volckmari) have semivoltine cycles as reported by Berthélemy \& Olmi (1978). Other authors (Bertrand, 1954; Nilsson, 1996) have also reported that the larvae of riffle beetles appear mostly during the winter in freshwater streams and that many species of this family can live in the larval state for two years. In the family Noteridae, the life cycle is univoltine with overwintering adults and with larvae during the summer in the north of Europe (Nilsson, 1996). In our study, we confirmed this cycle for $N$. laevis in a southern region (Fig. 2). Another life cycle that coincided with existing literature was that of the water strider A. najas (Fig. 2). This species has a univoltine cycle as indicated by Nieser et al. (1994). The single species of backswimmer captured in this study, A. sardeus, also has a univoltine cycle, with the last larval instars appearing in December and with overwintering adults.

In temperate regions, most species of Odonata have univoltine cycles, but some species can have a second generation in the same year if the conditions are favourable. Otherwise, their development can last several years (D'Aguilar et al., 1987). In this study, all dragonfly species had univoltine or semivoltine cycles. According to Askew (2004), the growth rate of Odonata larvae depends on the temperature. Dragonflies are not the only insects affected by this variable. Water temperature is one of the most important parameters that influence the development of aquatic insects (Nilsson, 1996; Cayrou \& Céréghino, 2005; Braune et al., 2008; Haidekker \& Hering, 2008). We found a significant correlation between water temperature and the total body length of two species: the coleopteran $N$. laevis $(R=0.92$, $p<0.05)$ and the dragonfly $B$. irene $(R=-0.73$, $p<0.05)$. $N$. laevis presents a positive correlation, with the last larval instars being captured during the months with the highest temperatures (summer). As mentioned above, this data confirms what Nilsson (1996) proposed for this species in a northern region. However, the body length of $B$. irene was negatively correlated with water temperature. The last larval instars were collected during the winter, when the tempera- ture was lower. We consider B. irene a "summer species" (sensu Corbet, 1954), with larvae growing slowly during the winter without diapause. Ferreras-Romero (1997) also described this type of cycle for this species in the south of Spain.

This study has served to analyse the life cycles of several species of aquatic insects in a southern area of the Atlantic biogeographical region. Some of these life cycles, including those of $N$. laevis, A. najas and B. irene, have already been reported in other regions; thus, we have confirmed what has been proposed by other authors. We can conclude that the "Gándaras de Budiño" wetland contains important communities of aquatic insects that must be conserved.

\section{ACKNOWLEDGEMENTS}

This study was supported by the Galician Government (PGIDIT02RFO30102PR). We want to thank Dr. Cesar João Benetti and Dr. Luis Felipe Valladares for their valuable comments.

\section{REFERENCES}

ASKEW, R. R. 2004. The dragonflies of Europe. Harley Books. Colchester. England. 308 pp.

BERTHÉLEMY, C. \& M. OLMI. 1978. Dryopoidea. In: Limnofauna Europaea. J. Illies (ed.): 315-318. G. Fischer. Stuttgart. Germany.

BERTRAND, H. 1954. Les insectes aquatiques d'Europe (Genres: larves, nymphes, imagos). Lechevalier. Paris. France. 556 pp.

BRACCIA, A., J. R. VOSSHEL \& V. D. CHRISTMAN. 2007. The Odonata of newly constructed ponds with life history and production of dominant species. Aquatic Insects, 29: 115-130.

BRAUNE, E., O. RICHTER, D. SÖNDGERATH \& F. SUHLING. 2008. Voltinism flexibility of a riverine dragonfly along thermal gradients. Global Change Biology, 14: 470-482.

CASADO, S. \& C. MONTES. 1995. Guía de los lagos y humedales de España. J. M. Reyero. Madrid. España. 255 pp.

CAYROU, J. \& R. CÉRÉGHINO. 2003. Life history, growth and secondary production of Caenis luctuosa and Cloeon simile (Ephemeroptera) in a small 
pond, S.W. France. Aquatic Insects, 25: 191-201. CAYROU, J.\& R. CÉRÉGHINO. 2005. Life-cycle phenology of some aquatic insects: implications for pond conservation. Aquatic Conservation: $\mathrm{Ma}$ rine and Freshwater Ecosystems, 15: 559-571.

CÉRÉGHINO, R., J. BIGGS, B. OERTLI \& S. DECLERCK. 2008. The ecology of European ponds: defining the characteristics of a neglected freshwater habitat. Hydrobiologia, 597: 1-6.

CHAPMAN, L. J., J. BALIRWA, F. W. B. BUGENYI, C. CHAPMAN \& T. L. CRISMAN. 2001. Wetlands of East-Africa: biodiversity, exploitation and policy perspectives. In: Biodiversity in Wetlands: Assessment Function and Conservation. B. Gopal, W. J. Junk and J. A. Davis (eds.): 101-131. Backhuys Publishers. The Netherlands.

CORBET, P. S. 1954. Seasonal regulation in British dragonflies. Nature, 174: 655-777.

CORBET, P. S., F. SUHLING \& D. SOENDGERATH. 2006. Voltinism of Odonata: a review. International Journal of Odonatology, 9: 1-44.

D'AGUILAR, J., J. L. DOMMANGET \& R. PRÉCHAC. 1987. Guía de las libélulas de Europa y África del norte. Omega. Barcelona. España. $352 \mathrm{pp}$.

DELLA BELLA, V., M. BAZZANTI \& F. CHIAROTTI. 2005. Macroinvertebrate diversity and conservation status of Mediterranean ponds in Italy: water permanence and mesohabitat influence. Aquatic Conservation: Marine and Freshwater Ecosystems, 15: 583-600.

DERKA, T., J. M. TIERNO DE FIGUEROA \& I. KRNO. 2004. Life Cycle, Feeding and Production of Isoptena serricornis (Pictet, 1841) (Plecoptera, Chloroperlidae). International Review of Hydrobiology, 89: 165-174.

FERNÁNDEZ, L. A. 2007. The annual life history of a population of the aquatic Coleopteran Derallus angustus (Coleoptera: Hydrophilidae). Revista de Biología Tropical, 56: 345-348.

FERRERAS-ROMERO, M. 1997. The life story of Boyeria irene (Fonscolombe, 1838) (Odonata: Aeshnidae) in the Sierra Morena Mountains (southern Spain). Hydrobiologia, 345: 109-117.

GARCÍA-CRIADO, F., E. BÉCARES, C. FERNÁNDEZ-ÁLAEZ \& M. FERNÁNDEZ-ÁLAEZ. 2005. Plant-associated invertebrates and ecological quality in some Mediterranean shallow lakes: implications for the application of the EC Water Framework Directive. Aquatic Conservation: Marine and Freshwater Ecosystems, 15: 31-50.
GARRIDO, J. 1990. Adephaga y Polyphaga acuáticos (Coleoptera) en la provincia fitogeográfica Orocantábrica (Cordillera Cantábrica). Ph. D. Thesis. University of León. 432 pp.

GARRIDO, J. \& I. MUNILLA. 2008. Aquatic Coleoptera and Hemiptera assemblages in three coastal lagoons of the NW Iberian Peninsula: assesment of conservation value and response to environmental factors. Aquatic Conservation: Marine and Freshwater Ecosystems, 18: 557-569.

GASTON, K. J., R. M. SMITH, K. THOMPSON \& P. H. WARREN. 2005. Urban domestic gardens (II): experimental tests of methods for increasing biodiversity. Biodiversity and Conservation, 14: 395413.

GEE, J. H. R., B. D. SMITH, K. M. LEE \& S. N. W. GRIFFITHS. 1997. The ecological basis of freshwater pond management for biodiversity. Aquatic Conservation: Marine and Freshwater Ecosystems, 7: 91-104.

GOPAL, B., W. J. JUNK \& J. A. DAVIS. 2001. Biodiversity in Wetlands: Assessment Function and Conservation. Backhuys Publishers. The Netherlands. $353 \mathrm{pp}$.

HAIDEKKER, A. \& D. HERING. 2008. Relationship between benthic insects (Ephemeroptera, Plecoptera, Coleoptera, Trichoptera) and temperature in small and medium-sized streams in Germany: A multivariate study. Aquatic Ecology, 42: 463-481.

HANQUET, D., M. LEGALLE, S. GARBAGE \& R. CÉRÉGHINO. 2004. Ontogenic microhabitat shifts in stream invertebrates with different biological traits. Fundamental and Applied Limnology (Archiv für Hydrobiologie), 160: 329-346.

HINDEN, H., B. OERTLI, N. MENETREY, L. SAGER \& J. B. LACHAVANNE. 2005. Alpine pond biodiversity: what are the related environmental variables? Aquatic Conservation: Marine and Freshwater Ecosystems, 15: 613-624.

HULL, A. 1997. The pond life project: a model for conservation and sustainability. Proceedings from the UK Conference of the Pond Life Project, 1: 101-109.

LÓPEZ-RODRÍGUEZ, M. J. \& J. M. TIERNO DE FIGUEROA. 2006. Life cycle and nymphal feeding of Rhabdiopteryx christinae Theischinger, 1975 (Plecoptera: Taeniopterygidae). Annales de la Société Entomologique de France, 42: 57-61.

MARM. 2008. Catálogo Nacional de Especies Amenazadas. Ministerio de Medio Ambiente y Medio 
Rural y Marino. http://www.mma.es/portal/secciones/biodiversidad/especies_amenazadas/

MITSCH, W. J. \& J. G. GOSSELINK. 2000. Wetlands. John Wiley and Sons. New York. USA. 920 pp.

NAVARRO-MARTÍNEZ, D., M. J. LÓPEZ-RODRÍGUEZ \& J. M. TIERNO DE FIGUEROA. 2007. The life cycle and nymphal feeding of Capnioneura petitpierreae Aubert, 1961 (Plecoptera, Capniidae). Illiesia, 3: 65-69.

NICOLET, P., J. BIGGS, G. FOX, M. J. HODSON, C. REYNOLDS, M. WHITFIELD \& P. WILLIAMS. 2004. The wetland plant and macroinvertebrate assemblages of temporary ponds in England and Wales. Biological Conservation, 120: 261-278.

NIESER, N., M. BAENA, J. MARTÍNEZ-AVILÉS \& A. MILLÁN. 1994. Claves para la identificación de los heterópteros acuáticos (Nepomorpha \& Gerromorpha) de la Península Ibérica -Con notas sobre las especies de las Islas Azores, Baleares, Canarias y Madeira. Publicación $n^{0} 5$. Asociación Española de Limnología. Madrid. España. 112 pp.

NILSSON, A. N. 1996. Aquatic insects of North Europe- A taxonomic handbook. Apollo Books. Stenstrup. Denmark. 274 pp.

OERTLI, B. 1993. Leaf litter processing and energy flow through macroinvertebrates in a woodland pond (Switzerland). Oecologia, 96: 466-477.

OERTLI, B., D. A. JOYE, E. CASTELLA, R. JUGE, A. LEHMANN \& J. B. LACHAVANNE. 2005.
PLOCH: a standardized method for sampling and assessing the biodiversity in ponds. Aquatic Conservation: Marine and Freshwater Ecosystems, 15: 665-679.

OERTLI, B., N. INDERMUEHLE， S. ANGÉLIBERT, H. HINDEN \& A. STOLL. 2008. Macroinvertebrate assemblages in 25 high alpine ponds of the Swiss National Park (Cirque of Macun) and relation to environmental variables. Hydrobiologia, 597: 29-41.

PÉREZ-BILBAO, A. \& J. GARRIDO. 2008. Diversidad de coleópteros acuáticos en las Gándaras de Budiño (zona LIC, Red Natura 2000) (Pontevedra, España). Bulletin de la Societé entomologique de France, 113: 343-350.

STATSOFT. 2004. STATISTICA computer program, version 7.0. By StatSoft, Tulsa, OK.

TRIGAL, C., F. GARCÍA-CRIADO \& C. FERNÁNDEZ-ÁLAEZ. 2006. Among-habitat and temporal variability of selected macroinvertebrate based metrics in a Mediterranean shallow lake (NW Spain). Hydrobiologia, 563: 371-384.

VEGA, M. J. \& P. DURANT. 2000. Fenología de efemerópteros y su relación con la calidad del agua del río Albarregas. Mérida, Venezuela. Revista de Ecología Latinoamericana, 7: 19-27.

VERDÚ, J. R. \& E. GALANTE. 2006. Libro Rojo de los Invertebrados de España. Dirección General para la Biodiversidad. Ministerio de Medio Ambiente. Madrid. España. 411 pp. 